\title{
KEWENANGAN KOMISI PEMBERANTASAN KORUPSI (KPK) DALAM PENGECUALIAN KERAHASIAAN BANK
}

Oleh

Tiara Ayu Lestari*)

\section{Abstrak}

Prinsip kerahasiaan bank yang dianut oleh perbankan di satu sisi sangat menguntungkan nasabah karena segala data keuangannya terjaga dengan aman, sedangkan di satu sisi dapat merugikan pihak-pihak tertentu yang dalam keadaan mendesak sangat membutuhkan informasi data keuangan nasabah tersebut. Namun di Indonesia kerahasiaan bank ini masih dapat dibuka atau ditembus oleh hal-hal tertentu berdasarkan ketentuan di dalam Undang-Undang Perbankan dan di luar UndangUndang Perbankan, salah satunya adalah oleh Komisi Pemberantasan Korupsi (KPK) dalam melakukan penyelidikan, penyidikan, dan penuntutan dalam kasus tindak pidana korupsi.

\section{Kata Kunci : Rahasia Bank, Komisi Pemberantasan Korupsi}

\section{A.PENDAHULUAN}

Tindak pidana korupsi di Indonesia sudah meluas dalam masyarakat. Perkembangannya terus meningkat dari tahun ke tahun, baik dari jumlah kasus yang terjadi dan jumlah kerugian keuangan negara maupun dari segi kualitas tindak pidana yang dilakukan semakin sistematis serta lingkupnya yang memasuki seluruh aspek kehidupan masyarakat. Kasus korupsi ini dilakukan dengan berbagai macam cara dan modus agar tidak tercium oleh pihak yang berwenang. Untuk menanggulangi semakin meluas dan bertambahnya kasus-kasus korupsi dan juga untuk memerangi tindak pidana korupsi ini, pemerintah telah membuat berbagai kebijakan yang tertuang dalam berbagai peraturan perundang-undangan, antara lain dalam Ketetapan Majelis Permusyawaratan Rakyat Republik Indonesia Nomor XI/MPR/1998 tentang

*) Penulis adalah Dosen Fakultas Hukum Universitas Islam Syekh Yusuf Tangerang
Penyelenggara Negara yang Bersih dan Bebas Korupsi, Kolusi, dan Nepotisme, Undang-Undang Nomor 28 Tahun 1999 tentang Penyelenggara Negara yang Bersih dan Bebas dari Korupsi, Kolusi, dan Nepotisme, serta Undang-Undang Nomor 31 Tahun 1999 tentang Pemberantasan Tindak Pidana Korupsi sebagaimana telah diubah dengan UndangUndang Nomor 20 Tahun 2001 tentang Perubahan atas Undang-Undang Nomor 31 Tahun 1999 tentang Pemberantasan Tindak Pidana Korupsi.

Buah dari berbagai kebijakan yang dikeluarkan oleh pemerintah tersebut adalah perlu adanya suatu badan yang dapat melaksanakan tugas dalam memerangi tindak pidana korupsi tersebut. Hal ini tertuang dalam UndangUndang Nomor 31 Tahun 1999 tentang Pemberantasan Tindak Pidana Korupsi, sebagaimana telah diubah dengan Undang-Undang Nomor 20 Tahun 2001 tentang Perubahan Atas UndangUndang Nomor 31 Tahun 1999 tentang 
Pemberantasan Tindak Pidana Korupsi, yang tertuang di dalam Pasal 43 ayat (1) dan (2) yaitu:

(1) Dalam waktu paling lambat 2 (dua) tahun sejak Undang-undang ini mulai berlaku, dibentuk Komisi Pemberantasan Tindak Pidana Korupsi.

(2) Komisi sebagaimana dimaksud dalam ayat (1) mempunyai tugas dan wewenang melakukan koordinasi dan supervisi, termasuk melakukan penyelidikan, penyidikan, dan penuntutan sesuai dengan ketentuan peraturan perundang-undangan yang berlaku.

Oleh karena itu, pada tahun 2002 dibentuklah suatu badan yang dinamakan Komisi Pemberantasan Korupsi (selanjutnya disebut "KPK"), dasar hukum dibentuknya KPK adalah adanya Undang-Undang Nomor 30 Tahun 2002 tentang Komisi Pemberantasan Tindak Pidana Korupsi pada tanggal 27 Desember 2002. Undangundang inilah yang menguatkan dibentuknya KPK yang merupakan lembaga negara yang dalam melaksanakan tugas dan wewenangnya secara independen dan bebas dari pengaruh kekuasaan manapun. KPK dibentuk dengan tujuan meningkatkan daya guna dan hasil guna terhadap upaya pemberantasan tindak pidana korupsi. Untuk dapat menjalankan tugasnya guna melakukan penyelidikan dan penyidikan kasus tindak pidana korupsi, KPK memerlukan data dan informasi yang akurat yang didapat dari berbagai pihak.

Salah satu pihak yang dapat dijadikan sumber informasi guna penyelidikan dan penyidikan kasus tindak pidana korupsi adalah lembaga keuangan perbankan. Bagaimana tidak, tindak pidana korupsi ini tidak terlepas dari adanya perputaran uang yang merupakan hasil dari tindakan korupsi tersebut yang bisa didapat dari penggelapan, penyogokan atau suap, pemerasan dan sebagainya. Lembaga yang sangat erat dengan bidang keuangan dan sering dijadikan tempat untuk menyimpan uang hasil korupsi adalah lembaga keuangan perbankan ini. Layanan perbankan sering dijadikan sebagai media atau alat dalam transaksi dan/atau menampung hasil tindak pidana korupsi. Layanan perbankan yang seringkali digunakan yaitu berupa layanan simpanan yang dapat berupa giro, tabungan, dan deposito, pengiriman uang atau transfer uang antar rekening bank, safe deposit box (kotak penyimpanan), dan layanan perbankan lainnya yang dapat dipergunakan oleh pelaku tindak pidana korupsi untuk menampung serta menyalurkan hasil tindak pidananya tersebut. Karenanya lembaga keuangan perbankan ini sering dijadikan salah satu media dalam rantai kasus pencucian uang atau dikenal dengan money laundering dari kasus tindak pidana korupsi.

Namun untuk dapat memperoleh informasi atau data mengenai transaksi keuangan, jumlah simpanan, penggunaan layanan perbankan lainnya, dan data nasabah bukanlah hal yang mudah didapat oleh semua orang. Sistem perbankan berdasarkan peraturan perundang-undangan bahwa bank harus menyimpan secara ketat segala informasi mengenai data nasabahnya, dan inilah yang di dalam dunia perbankan disebut dengan rahasia bank. Untuk itu, penulis perlu menjabarkan terlebih dahulu mengenai ruang lingkup mengenai rahasia bank ini yang mengalami perkembangan yaitu:

1. Undang-Undang Nomor 14 Tahun 1967 tentang Pokok-pokok Perbankan merumuskan rahasia bank adalah bank tidak boleh memberikan keterangan-keterangan ten- 
tang keadaan keuangan nasabahnya yang tercatat padanya dan halhal lain yang harus dirahasiakan oleh bank menurut kelaziman dalam dunia perbankan, kecuali dalam hal-hal yang ditentukan dalam undang-undang ini.

2. Undang-Undang Nomor 7 Tahun 1992 tentang Perbankan yang dimaksud dengan rahasia bank adalah segala sesuatu yang berhubungan dengan keuangan dan halhal lain dari nasabah bank yang menurut kelaziman dunia perbankan wajib dirahasiakan.

3. Undang-Undang Nomor 10 Tahun 1998 tentang Perubahan atas Undang-Undang Nomor 7 Tahun 1992 tentang Perbankan, rahasia bank adalah segala sesuatu yang berhubungan dengan keterangan mengenai nasabah penyimpan dan simpanannya.

Berdasarkan ketentuan di atas menunjukkan bahwa pengertian dan ruang lingkup mengenai rahasia bank dari Undang-Undang Nomor 14 Tahun 1967 tentang Pokok-pokok Perbankan dan Undang-Undang Nomor 7 Tahun 1992 tentang Perbankan mencakup lebih luas, karena berlaku bagi setiap nasabah dengan tidak membedakan antara nasabah penyimpan dan nasabah peminjam. Adapun ketentuan rahasia bank yang ditentukan dalam Undang-Undang Nomor 10 Tahun 1998 lebih sempit, karena hanya berlaku bagi nasabah penyimpan dan simpanannya saja.

Dengan memperhatikan latar belakang mengenai adanya rahasia bank tersebut yang dianut oleh lembaga keuangan perbankan, maka yang menjadi pertanyaan adalah:

1. Apakah rahasia bank ini bersifat tertutup bagi siapapun? Apakah ada hal-hal khusus yang dapat membuka rahasia bank ini?
2. Dapatkah KPK menembus kerahasiaan bank ini, guna kepentingan penyelidikan, penyidikan, dan penuntutan dalam kasus tindak pidana korupsi?

\section{B. PEMBAHASAN}

1. Pengecualian Rahasia Bank berdasarkan Undang-Undang Nomor 7 Tahun 1992 tentang Perbankan jo. Undang-Undang Nomor 10 Tahun 1998 tentang Perubahan atas Undang-Undang Nomor 7 Tahun 1992 tentang Perbankan

Ada dua teori mengenai rahasia bank di dunia yaitu teori rahasia bank yang bersifat mutlak (absolutely theory) dan teori rahasia bank yang bersifat relatif. Teori rahasia bank yang bersifat mutlak artinya bank mempunyai kewajiban untuk menyimpan rahasia atau keterangan-keterangan mengenai nasabahnya yang diketahui bank karena kegiatan usahanya dalam keadaan apapun juga, dalam keadaan biasa atau dalam keadaan luar biasa. Teori ini sangat menonjolkan kepentingan individu, sehingga kepentingan negara dan masyarakat sering terabaikan. Sedangkan teori rahasia bank yang bersifat relatif, bank diperbolehkan membuka rahasia atau memberi keterangan mengenai nasabahnya, jika untuk kepentingan yang mendesak, misalnya untuk kepentingan negara atau kepentingan hukum. Teori inilah yang dianut oleh Indonesia, adanya pengecualian dalam ketentuan rahasia bank memungkinkan untuk kepentingan tertentu suatu badan atau instansi diperbolehkan meminta keterangan atau data tentang keadaan keuangan nasabah yang bersangkutan sesuai dengan ketentuan perundangundangan yang berlaku. 
Implementasi dari teori rahasia bank yang bersifat relatif ini kemudan diatur di dalam ketentuan Pasal 40 ayat (1) Undang-Undang Nomor 7 Tahun 1992 sebagaimana telah diubah dengan Undang-Undang Nomor 10 Tahun 1998 tentang Perubahan atas Undang-Undang Nomor 7 Tahun 1992 tentang Perbankan (selanjutnya disebut dengan UU Perbankan) yang menyebutkan bahwa bank wajib merahasiakan keterangan mengenai nasabah penyimpan dan simpanannya, kecuali dalam hal sebagaimana dimaksud dalam Pasal 41, Pasal 41A, Pasal 42, Pasal 43, Pasal 44, dan Pasal 44A.

Adapun pengecualian tersebut adalah untuk hal-hal berikut:

1. Untuk kepentingan perpajakan

Mengenai pembukaan rahasia bank untuk kepentingan perpajakan ini diatur dalam ketentuan Pasal 41 ayat (1) UU Perbankan yang menyebutkan bahwa untuk kepentingan perpajakan, Pimpinan Bank Indonesia [sekarang oleh OJK] atas permintaan Menteri Keuangan berwenang mengeluarkan perintah tertulis kepada bank agar memberikan keterangan dan memperlihatkan bukti-bukti tertulis serta surat-surat mengenai keadaan keuangan nasabah penyimpan tertentu kepada pejabat pajak.

2. Untuk kepentingan penyelesaian piutang bank yang telah diserahkan kepada BUPLN/PUPN

Ketentuan pasal 41A UU Perbankan menentukan bahwa untuk penyelesaian piutang bank yang telah diserahkan kepada Badan Urusan Piutang dan Lelang Negara/Panitia Urusan Piutang Negara (BUPLN/PUPN), Pimpinan Bank Indonesia memberikan izin kepada pejabat BUPLN/PUPN untuk memperoleh keterangan dari bank mengenai simpanan nasabah debitur. Izin sebagaimana tersebut diberikan secara tertulis atas permintaan tertulis dari Kepala BUPLN/PUPN.

3. Untuk kepentingan peradilan dalam perkara pidana

Pembukaan terhadap ketentuan kerahasiaan bank dapat juga dilakukan dengan alasan untuk kepentingan peradilan dalam perkara pidana sebagaimana ditentukan oleh Pasal 42 UU Perbankan menentukan bahwa untuk kepentingan peradilan dalam perkara pidana, Pimpinan Bank Indonesia dapat memberikan izin kepada Polisi, Jaksa, atau Hakim untuk memperoleh keterangan dari bank mengenai simpanan tersangka atau terdakwa pada bank. Izin sebagaimana tersebut diberikan secara tertulis atas permintaan tertulis dari Kepala Kepolisian Republik Indonesia, Jaksa Agung, atau Ketua Mahkamah Agung.

4. Dalam perkara perdata antara bank dan nasabah

Menurut ketentuan Pasal 43 UU Perbankan bahwa dalam perkara perdata antara bank dengan nasabahnya, direksi bank yang bersangkutan dapat menginformasikan kepada pengadilan tentang keadaan keuangan nasabah yang bersangkutan dan memberikan keterangan lain yang relevan dengan perkara tersebut.

5. Dalam tukar menukar informasi antarbank

Ketentuan Pasal 44 ayat (1) UU Perbankan bahwa dalam rangka tukarmenukar informasi antarbank juga merupakan alasan untuk pembukaan atau penerobosan ketentuan rahasia bank yang menyatakan bahwa dalam rangka tukar-menukar informasi antarbank, direksi bank dapat memberitahukan keadaan keuangan nasabahnya kepada bank lain. Ketentuan ini tentu dapat dilakukan jika ada suatu kepentingan dari bank yang bersangkutan yang berkaitan dengan 
nasabah tersebut, dan tidak menimbulkan kerugian bagi nasabah.

6. Atas permintaan, persetujuan, atau kuasa dari nasabah penyimpan atau ahli warisnya

Selain untuk kepentingan dari negara, kepentingan penyelesaian perkara, dan kepentingan dari bank, UU Perbankan juga mengatur mengenai pengecualian kerahasiaan bank ini untuk kepentingan dari nasabah penyimpan yang diatur dalam Pasal 44A yaitu atas permintaan, persetujuan, atau kuasa dari nasabah penyimpan yang dibuat secara tertulis, bank wajib memberikan keterangan mengenai simpanan nasabah penyimpan pada bank yang bersangkutan kepada pihak yang ditunjuk oleh nasabah penyimpan tersebut. Dalam hal nasabah penyimpan telah meninggal dunia, maka ahli waris yang sah dari nasabah penyimpan yang bersangkutan berhak memperoleh keterangan mengenai simpanan nasabah penyimpan tersebut.

2. Pengecualian Terhadap Ketentuan Rahasia Bank Di Luar UndangUndang Nomor 7 Tahun 1992 jo. Undang-Undang Nomor 10 Tahun 1998 tentang Perubahan atas Undang-Undang Nomor 7 Tahun 1992 tentang Perbankan

Berdasarkan ketentuan UU Perbankan yang sudah dijabarkan sebelumnya mengenai pembukaan rahasia bank pada kondisi-kondisi tertentu yaitu hanya untuk kepentingan perpajakan; kepentingan penyelesaian piutang bank yang telah diserahkan kepada BUPLN/PUPN; kepentingan peradilan dalam perkara pidana; perkara perdata antara bank dan nasabah; tukar menukar informasi antarbank; dan atas permintaan, persetujuan atau kuasa dari nasabah penyimpan atau ahli warisnya. Berdasarkan UU Perbankan tersebut, maka KPK bukan merupakan salah satu pihak yang dapat membuka rahasia bank untuk bisa mendapatkan keterangan dan data keuangan tersangka atau terdakwa tindak pidana korupsi.

Mengapa KPK dinilai sangat perlu untuk dapat menembus rahasia bank ini? Karena salah satu hasil dari tindak pidana korupsi ini adalah uang dan benda berharga. Uang atau benda berharga ini biasanya disimpan, ditampung, atau dapat dipindahkan melalui jasa perbankan yaitu antara lain layanan simpanan yang dapat berupa giro, tabungan, dan deposito, pengiriman uang atau transfer uang antar rekening bank, safe deposit box (kotak penyimpanan), dan layanan perbankan lainnya. Perbankan menjadi media yang paling sering dan mudah digunakan dalam transaksi tindak pidana korupsi, oleh karena itu, salah satu sumber informasi data untuk dapat menyelidiki (calon) tersangka atau terdakwa tindak pidana korupsi adalah dari keterangan atau informasi keuangannya di bank. Berdasarkan hal tersebut sangatlah perlu bagi KPK untuk bisa mendapatkan kewenangan untuk bisa menembus kerahasiaan bank ini guna meminta keterangan kepada bank.

Jika dilihat kembali pada UndangUndang Nomor 31 Tahun 1999 sebagaimana telah diubah dengan UndangUndang Nomor 20 Tahun 2001 tentang Perubahan Atas Undang-Undang Nomor 31 Tahun 1999 tentang Pemberantasan Tindak Pidana Korupsi, dalam Pasal 29 menyebutkan:

(1) Untuk kepentingan penyidikan, penuntutan, atau pemeriksaan di sidang pengadilan, penyidik, penuntut umum, atau hakim berwenang meminta keterangan kepada bank tentang keadaan keuangan tersangka atau terdakwa. 
(2) Permintaan keterangan kepada bank sebagaimana dimaksud dalam ayat (1) diajukan kepada Gubernur Bank Indonesia sesuai dengan peraturan perundangundangan yang berlaku.

(3) Gubernur Bank Indonesia berkewajiban untuk memenuhi permintaan sebagaimana dimaksud dalam ayat (2) dalam waktu selambat-lambatnya 3 (tiga) hari kerja, terhitung sejak dokumen permintaan diterima secara lengkap.

(4) Penyidik, penuntut umum, atau hakim dapat meminta kepada bank untuk memblokir rekening simpanan milik tersangka atau terdakwa yang diduga hasil dari korupsi.

(5) Dalam hal hasil pemeriksaan terhadap tersangka atau terdakwa tidak diperoleh bukti yang cukup, atas permintaan penyidik, penuntut umum, atau hakim, bank pada hari itu juga mencabut pemblokiran.

Ketentuan pasal ini sebenarnya KPK mempunyai wewenang untuk dapat meminta keterangan kepada bank untuk kepentingan penyidikan, penuntutan, atau pemeriksaan di sidang pengadilan, dengan syarat permintaan keterangan kepada bank ini harus diajukan kepada Gubernur Bank Indonesia [sekarang kepada OJK] terlebih dahulu.

Kemudian terkait pula dengan Undang-Undang Nomor 30 Tahun 2002, KPK memiliki kewenangan untuk dapat membuka rahasia bank yang tercantum di dalam Pasal 12 huruf $\mathrm{c}$ dan $\mathrm{d}$ yaitu:

Dalam melaksanakan tugas penyelidikan, penyidikan, dan penuntutan sebagaimana dimaksud dalam pasal 6 huruf $c, K P K$ berwenang:

c) untuk meminta keterangan kepada bank atau lembaga keuangan lainnya tentang keadaan keuangan tersangka atau terdakwa yang sedang diperiksa;

d) memerintahkan kepada bank atau lembaga keuangan lainnya untuk memblokir rekening yang diduga hasil dari korupsi milik tersangka, atau pihak lain yang terkait.

Ketentuan pasal ini menerangkan bahwa KPK berwenang untuk meminta keterangan kepada bank, tanpa perlu mengajukan permintaan kepada Gubernur Bank Indonesia terlebih dahulu.

Adanya perbedaan ketentuan antara kedua undang-undang tersebut mengenai wewenang KPK untuk meminta keterangan kepada bank, maka hal inilah yang membuat Bank Indonesia perlu untuk mendapatkan kepastian mengenai kewenangan KPK untuk dapat meminta keterangan kepada bank, apakah harus dengan permintaan izin dari Gubernur Bank Indonesia terlebih dahulu atau tidak. Atas dasar hal tersebut dilayangkanlah Surat Gubernur Bank Indonesia No.6/2/GBI/GHk/Rahasia tanggal 8 Agustus 2004 yang meminta pertimbangan hukum dari Mahkamah Agung untuk menjawab persoalan kewenangan KPK dalam membuka rahasia bank, karena berdasarkan UU Perbankan yang dapat membuka rahasia bank hanya yang terdapat di dalam Pasal Pasal 41, Pasal 41A, Pasal 42, Pasal 43, Pasal 44, dan Pasal 44A saja, dan KPK tidak masuk ke dalam pihak yang dikecualikan di dalam membuka rahasia bank. Kemudian Mahkamah Agung menjawab surat dari Gubernur Bank Indonesia tersebut dengan mengeluarkan Surat Mahkamah Agung No.KMA/694/R.45/XII/2004 perihal pertimbangan hukum atas pelaksanaan kewenangan KPK terkait dengan 
ketentuan rahasia bank yang ditandatangani oleh Ketua Mahkamah Agung Republik Indonesia tanggal 2 Desember 2004, yang menyatakan bahwa dalam Surat Keputusan memuat penegasan hukum, bahwa ketentuan Pasal 12 Undang-Undang Nomor 30 Tahun 2002 tentang Komisi Pemberantasan Tindak Pidana Korupsi merupakan ketentuan khusus (lex specialis) yang memberikan kewenangan kepada KPK dalam melaksanakan tugas penyelidikan, penyidikan, dan penuntutan, tanpa perlu dilakukan pengajuan permintaan izin kepada Gubernur Bank Indonesia terlebih dahulu. Dengan berdasarkan ketentuan tersebut, maka prosedur izin membuka rahasia bank sebagaimana diatur dalam Pasal 29 ayat (2) dan ayat (3) Undang-Undang Nomor 31 Tahun 1999, sebagaimana telah diubah dengan Undang-Undang Nomor 20 Tahun 2001 tentang Perubahan Atas Undang-Undang Nomor 31 Tahun 1999 tentang Pemberantasan Tindak Pidana Korupsi, jo. Pasal 42 UU Perbankan, tidak berlaku bagi KPK mengenai permintaan izin kepada Gubernur Bank Indonesia terlebih dahulu.

Kemudahan akses yang diberikan kepada KPK ini merupakan terobosan hukum yang tepat, karena hal ini dapat juga menjadi upaya mencegah dan menindak tindak pidana di bidang perbankan yang salah satunya yaitu tindak pidana pencucian uang yang kerap merupakan bagian dari proses dalam kegiatan tindak pidana korupsi yang dilakukan oleh para tersangka atau terdakwa.

\section{Sanksi Atas Pelanggaran Keten- tuan Rahasia Bank}

Ketentuan rahasia bank sebagaimana telah dibahas di atas merupakan suatu ketentuan dimana bank sebagai pihak yang berkewajiban untuk menjaga segala keterangan mengenai nasabah penyimpan dan simpanannya, kecuali dengan hal-hal yang dapat membuka rahasia bank sesuai pembahasan tersebut di atas, namun dengan prosedur yang telah ditetapkan tentunya. Jika tidak dilaksanakan berdasarkan ketentuan yang berlaku, maka ada sanksi yang dapat diberikan kepada yang melakukan pelanggaran tersebut. Pelanggaran terhadap ketentuan rahasia bank tersebut telah diatur di dalam UU Perbankan yaitu pada Pasal 47 dan Pasal 47A.

Pada Pasal 47 UU Perbankan:

1) Barangsiapa tanpa membawa perintah tertulis atau izin dari Pimpinan $B I$ sebagaimana dimaksud dalam Pasal 41, Pasal 41A, dan Pasal 42, dengan sengaja memaksa bank atau pihak terafiliasi untuk memberikan keterangan sebagaimana dimaksud dalam Pasal 40, diancam dengan pidana penjara sekurang-kurangnya 2 (dua) tahun dan paling lama 4 (empat) tahun, serta denda sekurang-kurangnya Rp.10.000.000.000,- (sepuluh miliar rupiah) dan paling banyak $R p$. 200.000.000.000,- (dua ratus miliar rupiah).

2) Anggota dewan komisaris, direksi, pegawai bank atau pihak terafiliasi lainnya yang dengan sengaja memberikan keterangan sebagaimana dimaksud dalam Pasal 40, diancam dengan pidana penjara sekurang-kurangnya 2 (dua) tahun dan paling lama 4 (empat) tahun, serta denda sekurang-kurangnya Rp 4.000.000.000,- (empat miliar rupiah) dan paling banyak $R p$ 800.000.000.000,- (delapan ratus miliar rupiah).

Dari pasal tersebut dapat dikatakan bahwa siapa saja yang memaksa pihak bank atau pihak terafiliasi untuk memberikan keterangan sebagaimana dimaksud dalam Pasal 40 tanpa 
membawa perintah tertulis dari Gubernur Bank Indonesia, dan bagi anggota dewan komisaris, direksi, pegawai bank atau pihak terafiliasi lainnya yang secara sengaja memberikan keterangan yang wajib dirahasiakan menurut Pasal 40, maka dapat dikenakan sanksi berupa pidana penjara beserta denda yang telah ditentukan tersebut.

Selanjutnya ketentuan baru pada Pasal 47A UU Perbankan menyebutkan:

Anggota dewan komisaris, direksi, pegawai bank atau pihak terafiliasi lainnya yang dengan sengaja tidak memberikan keterangan yang wajib dipenuhi sebagaimana dimaksud dalam pasal 42A dan Pasal 44A, diancam dengan pidana penjara sekurangkurangnya 2 (dua) tahun dan paling lama 7 (tujuh) tahun serta denda sekurang-kurangnya Rp4.000.000.000,(empat miliar rupiah) dan paling banyak Rp15.000.000.000,- (lima belas miliar rupiah).

Pasal ini merupakan pasal tambahan yang ada di Undang-Undang Nomor 10 Tahun 1998, dalam pasal ini mengungkapkan bahwa bagi anggota dewan komisaris, direksi, pegawai bank, atau pihak terafiliasi yang tidak memberikan keterangan yang wajib dipenuhi, selama pihak yang meminta tersebut sudah memenuhi prosedur yang berlaku yaitu sebagaimana dalam Pasal 41 (untuk kepentingan perpajakan), Pasal 41A (untuk kepentingan penyelesaian piutang bank yang sudah diserahkan kepada BUPLN/PUPN), dan Pasal 42 (untuk kepentingan peradilan perkara pidana) akan dikenakan sanksi pidana penjara dan denda yang sudah ditentukan.

\section{PENUTUP}

Kerahasiaan bank ini bukanlah hal yang mutlak tertutup sama sekali dan tidak dapat ditembus oleh apapun dan siapapun di Indonesia, karena kerahasiaan bank di Indonesia bersifat relatif, artinya masih dapat ditembus dengan hal-hal tertentu berdasarkan ketentuan dalam UU Perbankan yaitu hanya untuk kepentingan perpajakan; kepentingan penyelesaian piutang bank yang telah diserahkan kepada BUPLN/PUPN; kepentingan peradilan dalam perkara pidana; perkara perdata antara bank dan nasabah; tukar menukar informasi antarbank; dan atas permintaan, persetujuan atau kuasa dari nasabah penyimpan atau ahli warisnya. Pelanggaran atas kerahasiaan bank ini dikenakan sanksi pidana penjara serta denda berdasarkan UU Perbankan yang berlaku.

Di luar UU Perbankan, KPK juga dikecualikan dalam kerahasiaan bank, KPK berwenang untuk meminta keterangan kepada bank guna kepentingan penyelidikan, penyidikan, dan penuntutan, tanpa perlu mendapatkan izin dari Gubernur Bank Indonesia. Hal ini ditegaskan dalam Surat Mahkamah Agung No.KMA/694/R.45/XII/2004 perihal pertimbangan hukum atas pelaksanaan kewenangan KPK terkait dengan ketentuan rahasia bank, ketentuan Pasal 12 huruf (c) dan (d) Undang-Undang Nomor 30 Tahun 2002 tentang Komisi Pemberantasan Tindak Pidana Korupsi menyampingkan ketentuan Pasal 29 ayat (2) dan ayat (3) Undang-Undang Nomor 31 Tahun 1999, sebagaimana telah diubah dengan Undang-Undang Nomor 20 Tahun 2001 tentang Perubahan Atas Undang-Undang Nomor 31 Tahun 1999 tentang Pemberantasan Tindak Pidana Korupsi, jo. Pasal 42 UU Perbankan. 


\section{DAFTAR PUSTAKA}

1. Literatur

Djumhana, Muhammad, Hukum Perbankan di Indonesia, Bandung: PT Citra Aditya Bakti, 2012.

Hermansyah, Hukum Perbankan Nasional Indonesia, Jakarta: Prenadamedia Grup, 2005.

Husen, Dadang, Hukum Perbankan di Indonesia, Bandung: CV Pustaka Setia, 2016.

Kasmir, Bank dan Lembaga Keuangan Lainnya, Jakarta: PT Rajagrafindo Persada, 2014.

Usanti, Trisandini P, dan Abd. Somad, Hukum Perbankan, Depok: Kencana, 2017.

\section{Peraturan Perundang-Undangan} Undang-Undang Nomor 7 Tahun 1992 tentang Perbankan, Jakarta: Kementerian Negara Sekretaris Negara Republik Indonesia, 1992.
Undang-Undang Nomor 10 Tahun 1998 tentang Perubahan Atas Undang-Undang Nomor 7 Tahun 1992 tentang Perbankan, Jakarta: Kementerian Negara Sekretaris Negara Republik Indonesia, 1998.

Undang-Undang Nomor 31 Tahun 1999 tentang Pemberantasan Tindak Pidana Korupsi, Jakarta: Kementerian Negara Sekretaris Negara Republik Indonesia, 1999.

Undang-Undang Nomor 20 Tahun 2001 tentang Perubahan Atas Undang-Undang Nomor 31 Tahun 1999 tentang Pemberantasan Tindak Pidana Korupsi, Jakarta: Kementerian Negara Sekretaris Negara Republik Indonesia, 2001.

Undang-Undang Nomor 30 Tahun 2002 tentang Komisi Pemberantasan Tindak Pidana Korupsi, Jakarta: Kementerian Negara Sekretaris Negara Republik Indonesia, 2002 